\title{
The Effects of Terrorist Activities on Development in the Southeastern Region of Turkey-Theoretical and Empirical Application
}

\author{
Mustafa Mete ${ }^{1}$ \\ ${ }^{1}$ Faculty of Economics and Business Administration, Gaziantep University, Turkey \\ Correspondence: Mustafa Mete, Faculty of Economics and Business Administration, Gaziantep University, \\ Turkey. Tel: 903-423-172-045. E-mail: mete@ gantep.edu.tr
}

Received: January 22, 2016

Accepted: March 8, 2016

Online Published: March 25, 2016

doi:10.5539/ijef.v8n4p229

URL: http://dx.doi.org/10.5539/ijef.v8n4p229

\begin{abstract}
Terrorist activities affect and continue to cause social, political, cultural and economic problems for Turkey just as they do to many parts of the world. Investors would prefer to move their capital into safer regions due to the problem of terrorism and this affects the distribution of development. This study, aims at demonstrating the extent at which terrorism has affected development in the South-eastern Anatolia region of Turkey. This study will look at the investment volumes in 9 provinces located in southeast Turkey. We will also look at terrorist activities in these provinces as well as discussing the relationship between investment preferences and terrorism. Firstly, we will look at terrorist incidents in these provinces, the number of provinces affected by terrorist activities, number of people dying from terrorist related activities, state and industrial investments as well as determining the number of industrial workers in these provinces. For this purpose, as a case study, we will investigate investments in Gaziantep which is a city located in the Southern eastern Anatolia region and the sixth largest city in Turkey with a lot of private investments. In this study, a questionnaire was administered to ninety-three (93) big companies who are doing foreign trade with at least one country. The questionnaire administered was easy and used a detailed cross-question analysis. According to the study, it was discovered that there is an inverse relationship between the private investment demand and the frequency of terrorist incidences and then this relationship was discussed in detail.
\end{abstract}

Keywords: terrorism and security, Turkish economy, growth and development, South-eastern Anatolia region, regional economy

\section{Introduction}

Today, it is believed that regional policies have been very important concept in macroeconomic policies of the countries (Arslan \& Mete, 2007). Regional science and regional economics, which had tended to be somewhat marginalized, has now become a focus of attention (Sboui \& Hammas, 2010). Today, terrorism is no longer a problem affecting one region or country, it is a problem affecting all regions and states of the world in one way on the other (Baharçiçek, 2000). Terrorist organizations are using social, cultural, racial, political, religious, nationality as well as various ideological elements to bring people together. The terrorist organizations' activities are also bringing about social, cultural, political and most importantly security problems. These in turn have a negative impact on the economy leading to adverse economic issues. Most articles or research publications that have examined the relationship between terrorism and economic development have discovered that in areas, regions or countries with more terrorist activities or with the possibilities of terrorist activities, investments are either low, delayed or never take place and consequently, terror activities have a negative impact on development (Abadie \& Gardeazabal, 2003; Brucke \& Wickström, 2004). In particular, uncertainty created by the terrorist attacks leads to delayed investments and severely affects the performance of financial markets (Dow \& Werlang, 1992; Chesney, Reshetar, \& Kahraman, 2011). Particularly in regions where terrorist activities originate from ethnic and religious backgrounds, economic growth and regional investments come to a halt. For example, an increase in internal conflicts in Israel (rise in terrorism) the amount of income per capita in the period between 2000-2003 decreased by 3\%, foreign trade volume decreased to $45 \%$ from 55\% and the expenditures on defence in 2003 increased by 3\% compared to 2000 (Eckstein \& Tsiddo, 2004; Cukierman, 2004). A similar situation exists in Spain where ethnic and cultural differences can be given as an example. In the Spain's Basque region, the growing terrorist activities from the 1970 and their continued rise until the late 1990s, saw a significant 
decrease in GDP, population loss as well as a decrease in per capita due to the decrease in revenue (Abadie \& Gardeazabal, 2003). The pressure of terrorism on the Pakistani economy still continues. As terror activities put limitations on trade and flow of capital investments, it also puts pressure on the prices of goods and services which go up and in that way triggering high inflation (Malik \& Zaman, 2013). The Taliban hinders real investments and infrastructure development. Due to this instability and lack of security, it is hard for companies and individuals to invest in Pakistan. The negative impacts of terrorism are not only limited to these countries. In one study, it was discovered that in many less developed and developing countries, terrorism has resulted in the reduction of both GDP and GNP as well as impacting negatively on the productivity of the whole economy (Shahrestani \& Anaraki, 2008, pp. 47-48). Besides, particularly in countries with developed economies, considerable amounts of resources are set aside to prevent terrorism (Llussá \& Tavares, 2011). For example, after the September 11 terrorist attacks, the United States of America allocated 262.5 billion dollars in a period of 3 years to fight terrorism (Lakdawallaa \& Zanjani, 2005).

Turkey, just like many other countries in the World, faces terrorism challenges. Although there are many causes of terrorist events in the world, Terrorism activities experienced by Turkey are closely related to her geography (Ozturk, 2009). The south-eastern part of the country lies in the region where the intensity of terrorist activities is high. In fact, most of the studies done on terrorism in Turkey bear testimony to this notion (Yeşiltaş et al., 2008; Baharçiçek, 2000; Sezgin, Gündüz, \& Sezgin, 2008; Töreli, 2002; Unur, 2000; Bal, 2007; İşeri, 2008).

Mainly due to propaganda by nationalist ethnic groups and the PKK terrorist group which was founded in 1974. The studies found out that these were the main contributing factors to armed conflicts and loss of lives in the south-eastern region of Turkey (Töreli, 2002, p. 37). Whilst these factors were having adverse effects both economically and socially in the provinces of Adiyaman, Diyarbakır, Mardin, Şırnak and Siirt, they had little effect on the province of Gaziantep (Sezgin, Gündüz, \& Sezgin, 2008). The PKK expanded its operations and had made great strides in their ambitions in the border regions of Turkey as well as regions with political instability (Mardin, Sirnak, \& Siirt). The PKK terrorist organization using its ethnic nationalist ideology gained support from Kurds living in the border regions of Turkey's neighbouring countries of Syria, Iran and Iraq. And indeed the percentage of participation in the terrorist activities in Turkey was $12.49 \%$ from Syria, 9.89\% from Iran and 3,72's\% of those participating were born in Iraq (Parliament, 2013). For this reason, there was an increase of PKK's importance and effectiveness in the border regions and these became the priority areas for the group. The PKK therefore increased its presence and activities as well as becoming the authority where people would take heed of what the PKK has said. If it would be possible, we would state today that there emerged two management authorities in the South-eastern region of Turkey - one was the PKK and the second one the Turkish government. This influenced the decisions regarding the future of the regions as well as direction of economic investments. Nevertheless, the general economic changes in the south-eastern region of Turkey was reflected especially in the regions around the Tigris river bed. The non-realization of the expected economic development in the region appears to be due to terrorism and also as a result of the unsafe conditions and uncertainties in the political future of the region. Regional sustainable development must be initiated and accepted by the local and regional authorities and dynamics. Their support and cooperation will in turn foster positive results. The level of cooperation and trust will yield corresponding degree of success (Çetin, 2006). This is why, in this study, the relationship between terror activities and instability as well as uncertainty in the south-eastern region of Turkey was discussed and evaluated. In this context, using statistical data, a quantitative analysis of spatial distribution of economic investments was conducted and its conclusions were drawn from the results obtained.

\section{Material and Method}

In this study, first we look at the spatial distribution of terrorist acts. Data on terrorism has been obtained from reports prepared by Turkish Parliament in 2013. The obtained data were used in the creation of distribution maps and various tables. In this study, we looked at the 6th largest city in the South-eastern Anatolia Region of Turkey and we dwelt on the investors in Gaziantep province which is ranked 3rd largest in Turkey in the textile and Food sector. Owners of firms in Gaziantep province doing export to at least one country were both interviewed and a questionnaire administered to them. In this context, of 600 businessmen from the organized industrial area in Gaziantep, 93 were reached through this survey. The results obtained were evaluated using the SPSS program. From the analysis that was made, it was revealed that in areas with high concentration of terrorist activities, there is a relationship between terrorism and the desire for investors to invest in the areas with high occurence of terrorist activities.

\subsection{The Escalation of Ethnic Terrorism in Southeastern Anatolia Region of Turkey}

South-eastern Anatolia Region covers about 57 thousand square kilometres area and is surrounded by the Taurus 
Mountains to the North and Southeast. To the west is Mediterranean region (Turkey), to the north and from the east it borders the East Anatolia region of Turkey. To the south there is the Turkish political border with Syria and Iraq. The provinces that make up the region are Adiyaman, Gaziantep, Kilis and Sanliurfa which lie in the Euphrates basin and Batman, Diyarbakır, Mardin, Siirt and Şırnak which are located in the Tigris basin (Figure 1).

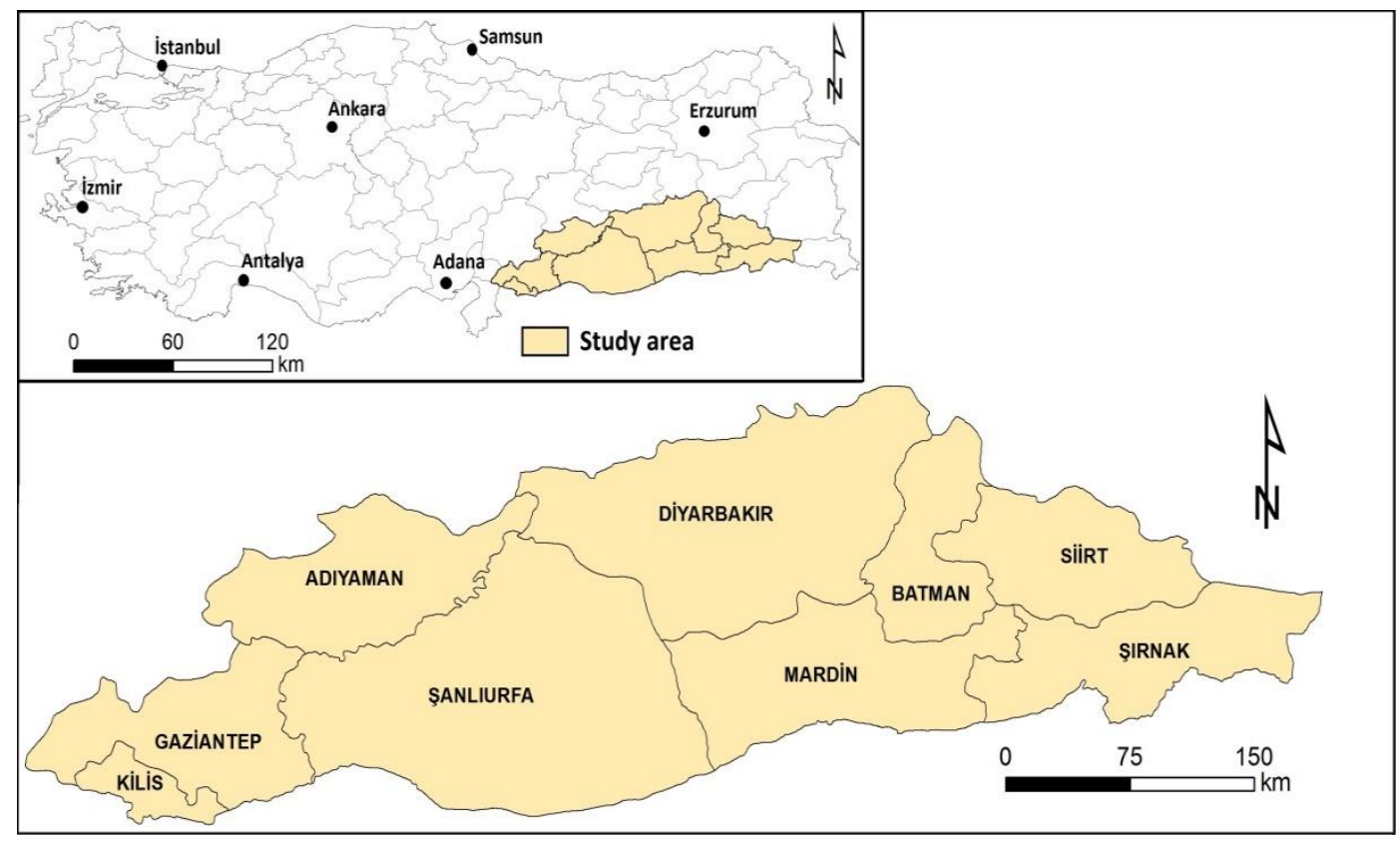

Figure 1. Study area

The period of terror activities from 1984 to 2013 in Turkey had an impact on population distribution and determined the direction of economic investment and also brought about security issues. Eastern part of the South-eastern Anatolia Region was the most affected by this situation. The terror activities in Turkey have ethnic and regional origins dating back to the 1980s. The PKK is a terrorist organization that holds a high percentage of terrorist activities in the region. 1984 marked the year PKK began an armed struggle against the Turkish government. The terrorist activities that started slowly in the 1980s started rising rapidly in the 1990s. From 1984 until 1990, a total of 633 people involved in terrorist activities were killed. Due to the rise in terrorist activities from 1990 to 1995, the total number of people that died from terrorist activities increased to 8244 within a five year period. This intense conflict continued between the years 1995-2000 and during this period the number of the dead from terrorist activities reached 7993 (Figure 1). In the later years, the Turkish government started to negotiate with the PKK in order to find a political solution to the problem. This led to the decrease in the number of deaths from terror related activities. Between the years 2000-2005, the total number of deaths due to terrorism dropped to 750. The total number of deaths due to terrorism for a 7 year period from 2005-2012 stood at 2029 (Figure 2). According to official sources, 7918 were people killed in terrorist related activities during the period from 1984 to 2013.

The increase in terrorist activities led to an increase in civilian deaths. Indeed, it can also be noted that the increase in the deaths of people perceived as terrorists is parallel to the increase in civilian deaths. The period from 1990 to 1995 saw an increase in the number of terrorist deaths and the number of civilian deaths reached 2680. In the period between 1984-2012 (29 year period) the total number of civilian deaths was 3924 which represented $68 \%$ of total deaths. Without doubt, the region that experienced most civilian deaths was the Southeastern Anatolia region. In Turkey, we can see that the highest percentage share of the terrorist activities in the Southeastern Anatolia region by province is as follows; Diyarbakır 16.2\%, Mardin 12.8\%. These two are followed by Van province in the East and Sirnak province in the South East (Turkish Parliament report, 2013). We can also see that the PKK is the most prominent organization in terms of terrorist activities in the South Eastern region. The province of Sirnak registered the most armed clashes between the Turkish Armed forces and 
the PKK. This was followed by the provinces of Siirt, Diyarbakır and Mardin respectively.

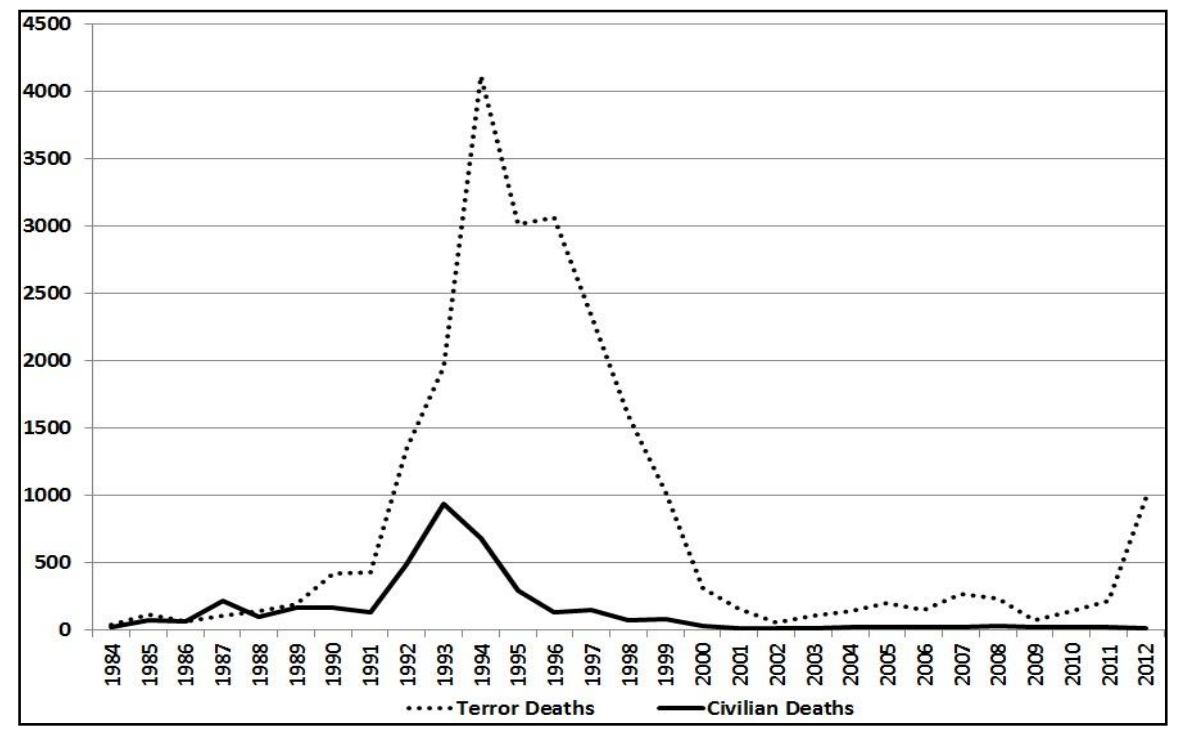

Figure 2. The total number of deaths due to terrorism

Looking at the participation in terrorist activities and incidents by province, we can see that Diyarbakır province is the highest with 17.6\%. After Diyarbakir, Mardin province in the Southeast comes second. These are followed by the provinces of Şırnak 6.8\%, Batman 4.1\%, Siirt 3.6\% Şanlı Urfa 2.9\% and Gaziantep 1\%, Adıyaman 1\% and Kilis 1\% (figure 3). The percentage participation of people in terrorist activities in the Southeastern region comprises of $45.8 \%$ of total participation in terrorist activities in Turkey.

In Turkey generally, $46.8 \%$ of deaths captured due to terrorism occurred in the South-eastern Anatolia region. Across the region, $18.2 \%$ of deaths occurred in Sirnak, Siirt 10.4\%, 8.9\% in Diyarbakir, Mardin 5.4\%, 3.4\% in Batman remaining percentage of less than 1\% occurred in Gaziantep, Sanliurfa, Adiyaman and Kilis (Figure 2).

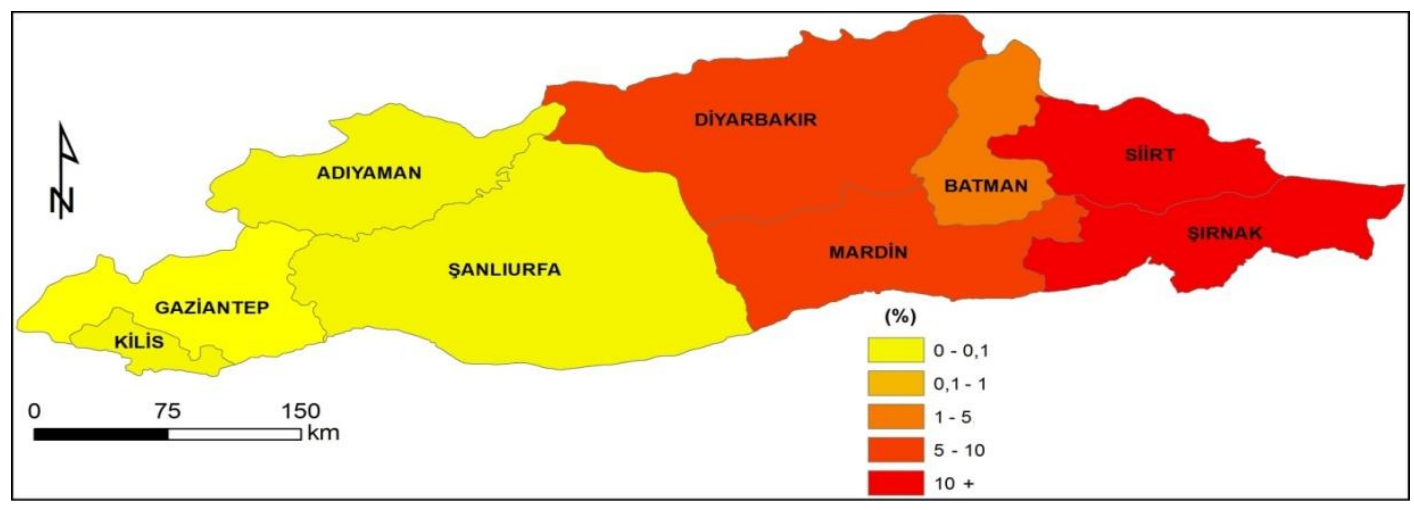

Figure 3. Distribution of those captured dead in terrorist events in the region

Looking at the distribution of the participation in terrorist activities by province. It can be seen that in general, the highest participation rate is in Diyarbakır with 17.6\%. After the Diyarbakir province in southeast Anatolia region is Mardin with $10.8 \%$. These are followed by Şırnak with $6.8 \%$, Batman $4.1 \%$, Siirt 3.6\%, Şanlıurfa $2.9 \%$ and Gaziantep, Adiyaman and Kilis at 1\%. The number of people involved in the terrorist activities in provinces in the southeast Anatolia region corresponds to $45.8 \%$ of total participation in Turkey. 


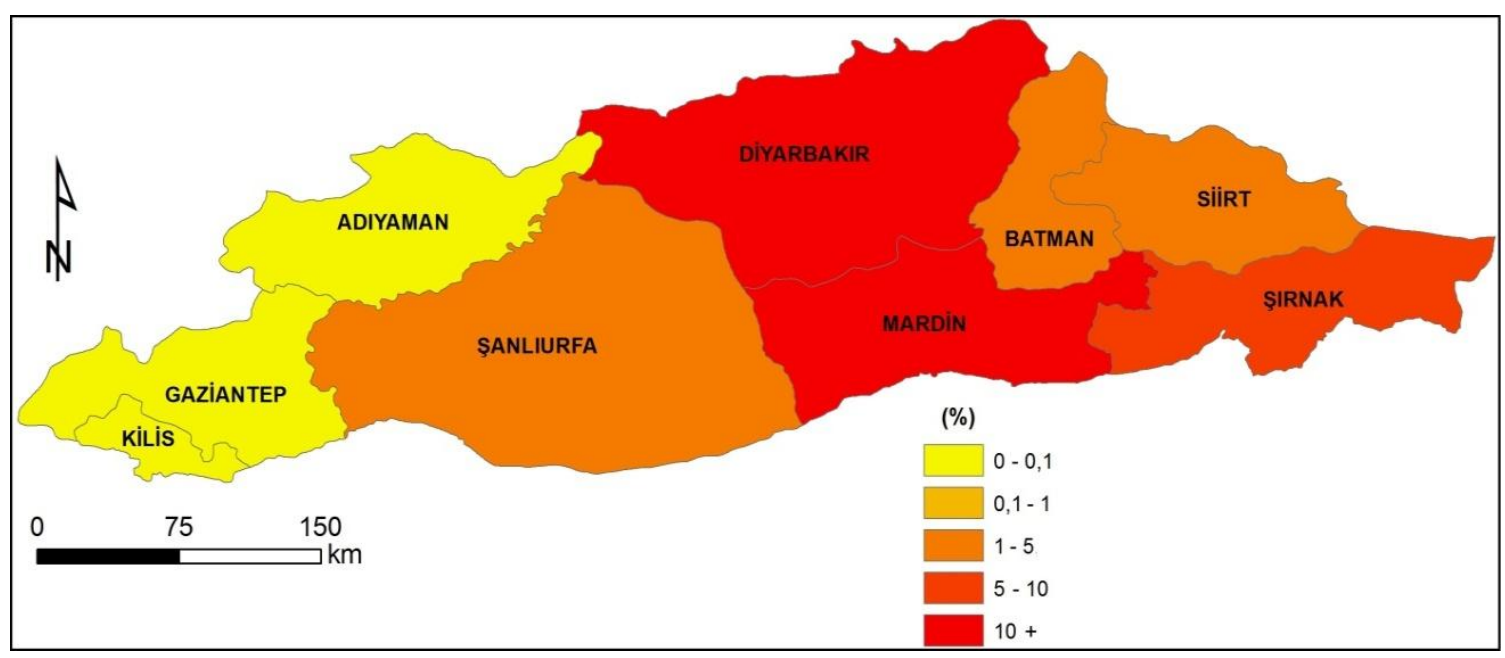

Figure 4. Provincial rate of participation in terrorist activities

Taking into account the place of birth of individuals participating in a terrorist activities in Turkey, it can be seen that the Southeastern Anatolia region comes first. By place of birth, the province with the highest rate of participation in terrorist activities is Diyarbakır with $16.2 \%$, Mardin $12.8 \%$, Şırnak $6,9 \%$, Siirt $6 \%$, Şanlıurfa $5.1 \%$, Batman $4.1 \%$, Adiyaman $1.5 \%$ and Gaziantep and Kilis around $1 \%$. These provinces account for around $52.7 \%$ of the total number of terrorist activities in Turkey.

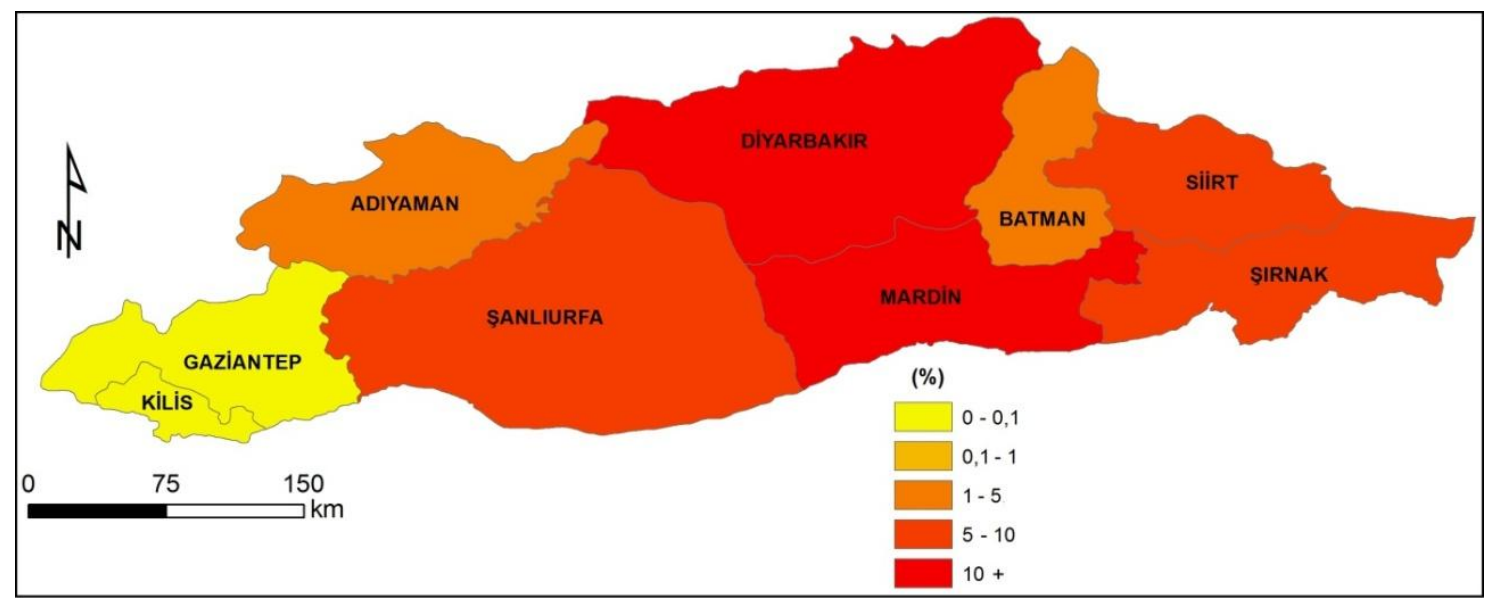

Figure 5. Participation rate by place of birth

There is a close relationship between the increase in population displacement in the region and terrorism. This is intensive migration in areas where ethnicity and terrorism related deaths and participation are intense. Indeed, the net migration rate between the provinces in the South eastern Anatolia region was the lowest in the years from 1980-1985. This could be attributed to the fact that during this period, terrorism had not emerged in the region. But the following years from 1985-1990 saw an important increase in net migration. This situation corresponds to the period of the emergence of terrorism and this led to serious migration from rural areas in particular. In the period between the years 1985-1990, most of the immigration occurred mainly to the main cities of Istanbul, Izmir, Adana and the major cities of western Turkey, such as Bursa (Avc1, 2003). Despite the fact that the most exacerbated period was from 1990-2000, it can also be observed that there was a reduction in the net migration in some provinces within the same period. The migration that came about in most instances was movement from rural areas to the provincial. 


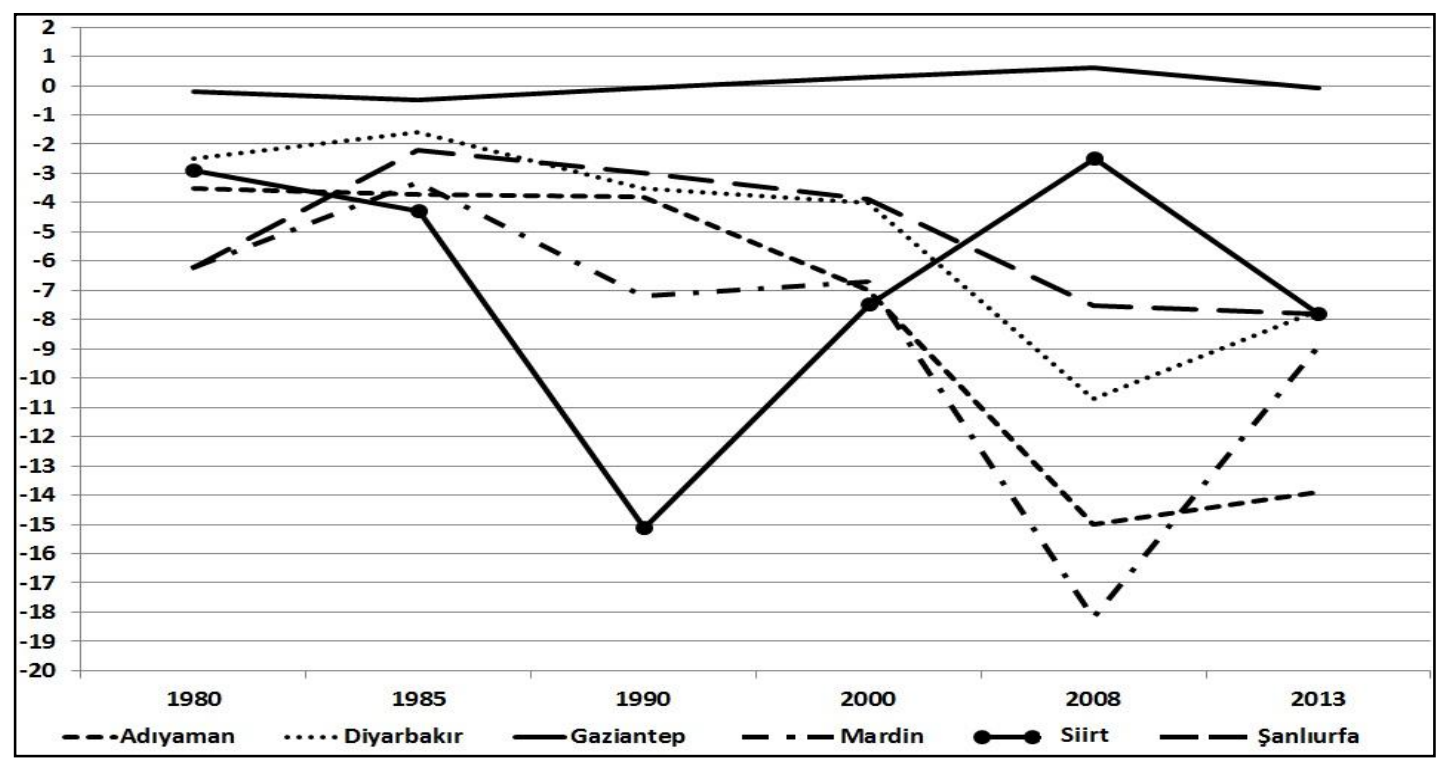

Figure 6. Net migration rates of the provinces in Southeastern Anatolia region

centres and cities as well as to new provinces. And indeed most of the migration that occurred in the period from 1990-2000 was from rural areas to areas that became provinces after 1990 like Batman, Şırnak and partly Kilis and which cannot be seen in the graph. In this case, the form of migration that occurred in the south eastern Anatolia region was in part migration within the province and on the other part migration to other provinces. For example, Kiziltepe (Mardin) had a population of 60000 in 1990 but this population rose to above 113000 by the year 2000. Similarly, in 1990 the province of Batman city's population was 193000 and by in 2000 the population had exceeded 304000 and by 2013 had exceeded 420000 to (TÜİK, 2014). Due to the security problems experienced in the surrounding provinces, the people were forced to move and settle in these areas. According to one research that was conducted, it was discovered that in 14 provinces in the south eastern region of Turkey, 62,448 households which represented 386,360 persons were forced to flee from their villages due to security problems (TBMM, 2013). Besides, particularly from Sanliurfa and other provinces most of the emigration was to Gaziantep. In the course of time, the intensity of westward migration started growing.

Besides, in recent years, the PKK terrorist organization has begun to establish structures inside some cities and began conducting terrorist activities inside the cities. These actions are substantially getting lower from one year to another from 1990-2000 depending on the political situation. The big part of the terrorist activities were in direct response to the actions of the Turkish government. In general, the terrorist activities have a negative impact on private investments but the most affected was the south eastern Anatolia region. Since the establishment of the Republic, in regions with low government investments, the government in recent years is putting more effort to compensate for this. And if we look at the period from 2010-2013, the state per capita investment was the high in areas with terrorism incidences like Adiyaman, Diyarbakır, Mardin, Batman and Şirnak. In contrast, in areas with less terrorist activities like Gaziantep, generally, the amount of state investment was lower. In contrast, in areas with less or no terrorist activities like Gaziantep, generally, the amount of state investment was lower. For Example; In the period between 2010-2013 Mardin had per capita state investment of 3,483 TL per year (about 1,515 dollars), Adiyaman had 2,382 TL (about 1,010 dollars), Kilis 1,652 TL(about 720 dollars) Diyarbakir, 1,520 TL (about 670 dollars), Batman, 1,368 TL (about 600 dollars), Sanliurfa 1,175 TL (about 510 dollars), Sirnak 853 TL (about 370 dollars), Siirt 718 TL (about 312 dollars) and Gaziantep 572 TL (a bout 250) TL (Figure 7). 


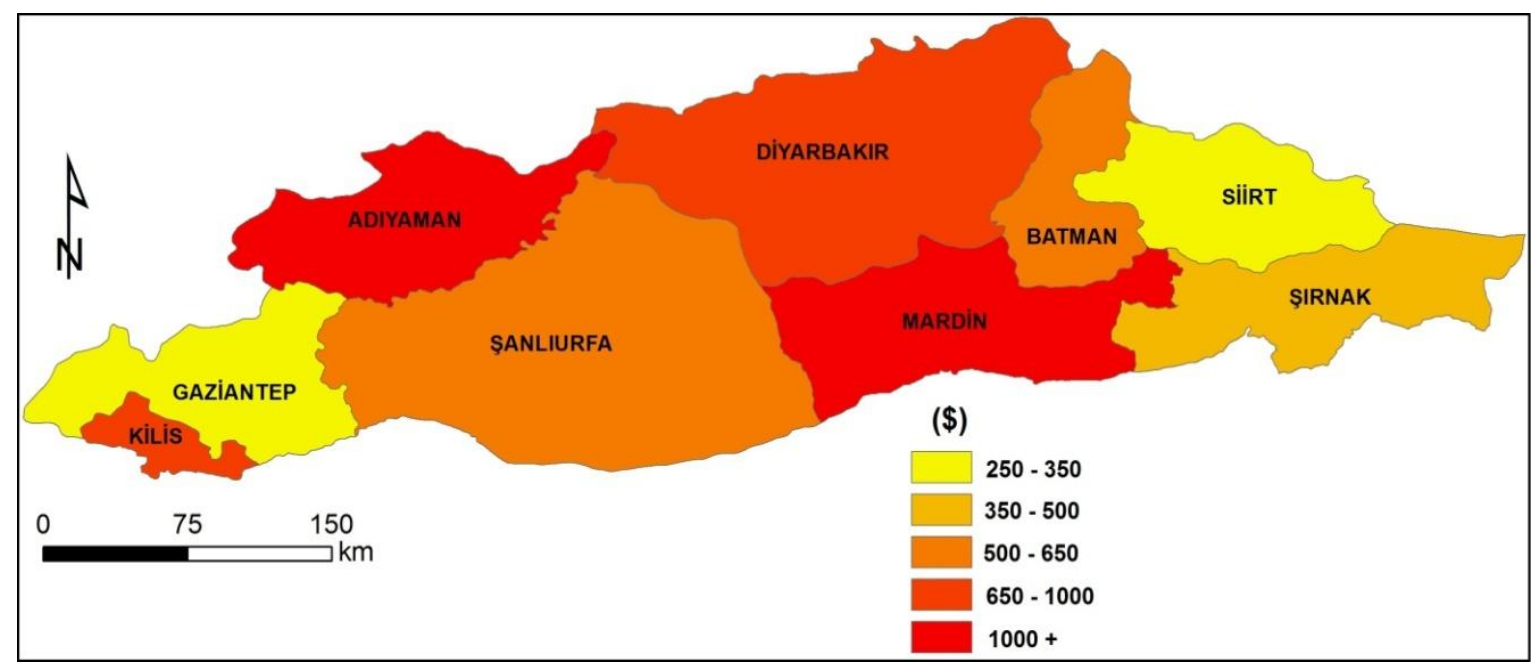

Figure 7. The average annual per capita state spending made the south eatern region

When we look at the degree of government support or the level of government investment incentives, the south eastern Anatolia region ranks 6th in the country. Whilst Batman, Diyarbakır, Mardin, Siirt, Şanlıurfa and Şırnak remain ranked 6th in terms of the degree of investment promotion, Adiyaman and Kilis are ranked 5th and only Gaziantep ranked 3rd (Figure 8). Be it the per capita government expenditure or the level of investment promotion, it can be seen that the eastern part of the region was more advantaged.

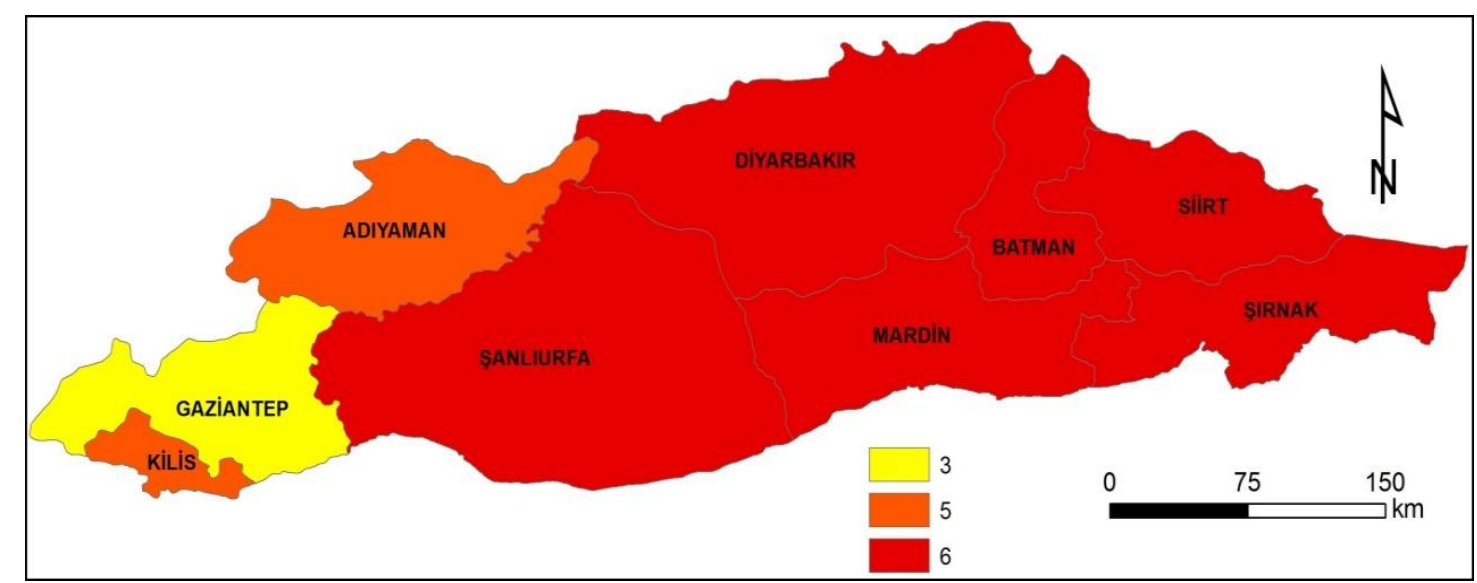

Figure 8 . Distribution by province of Incentive rate in the region

The distribution of industrial establishments in the South-eastern Anatolia Region vary considerably. According to 2013 data, there was a total of 4037 industrial companies in the region. Of these companies, $2146(53 \%)$ were in Gaziantep province. 592 companies (15\%) are in Şanlıurfa, 446 companies (11\%) in Diyarbakır, 235 companies (5.8\%) in Adıyaman, 230 companies (5.6\%) in Mardin, 194 companies (4.9\%) in Batman, 71 companies (1.7\%) in Şırnak, 65 companies (1.6\%) in Kilis and 58 companies (1.4\%) in Siirt (Figure 9).

If this data is to be taken into consideration, the number of industrial enterprises declines considerably from the east towards the west of the region. Besides this, especially where population density is high, it can be observed that in these areas there is a high concentration of industries. A wide variety of incentives are implemented in terms of promoting regional development. These investment incentives include; tax exemptions, customs duty exemptions, Value added tax support, incentive, premium, land allocation, special discount rates on income tax, electricity subsidies and others that may be applied to promote investments. An effective incentive system based on a coherent regional development policy plays an important role in the reduction of regional imbalances (Yayar \& Demir, 2012). 


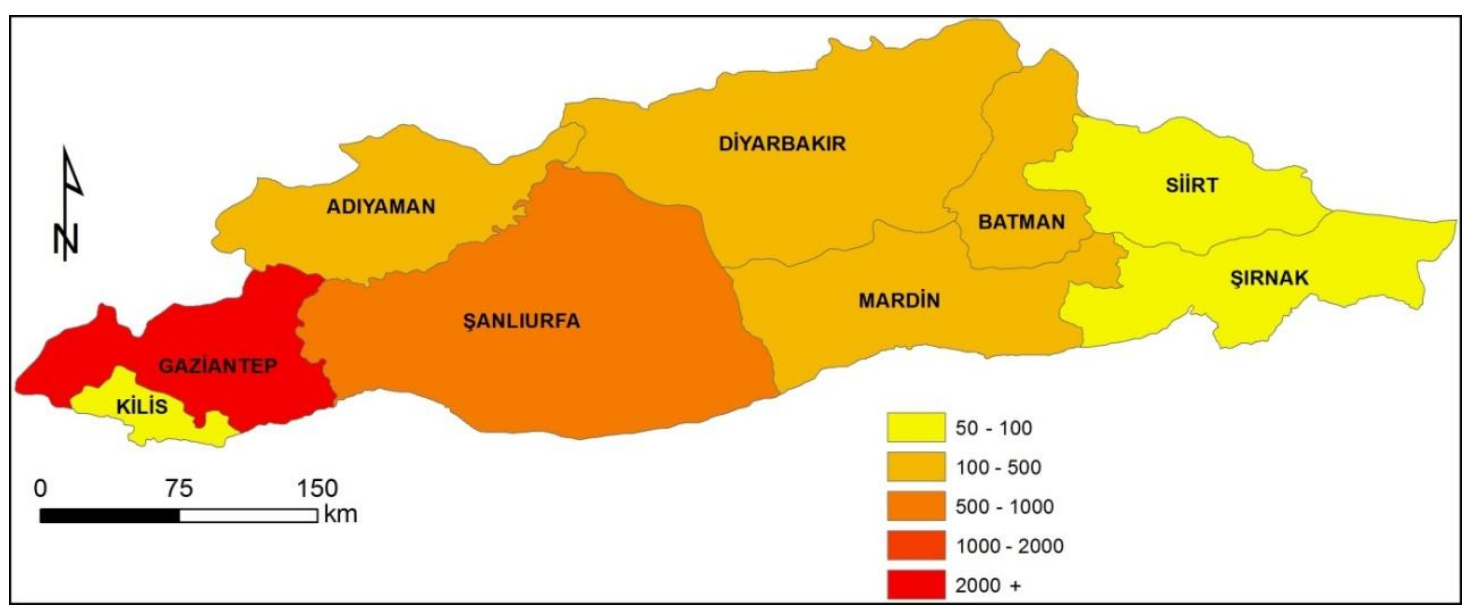

Figure 9. The provincial distribution of industrial enterprises in the region

Looking at the distribution of the number of employees in industrial enterprises in the region it can be observed that this is parallel to the density of industries in the region. The number of industrial employees in the region is about 133, 000 people. $63.2 \%$ of these employees ( 84102 people) is for Gaziantep province alone. As is the case with the number of industries, in second place is Sanliurfa with 12931 persons representing 9.7\%, Diyarbakır employs 10654 people which represents $8 \%$, Adıyaman employs 9055 people which accounts for $6.8 \%$, Batman has 6371 industrial employees representing 4.8\%, Mardin employs 5256 which is 4\%, 1724 people in Siirt which represents and Şınak has 1690 people employed which is $1.3 \%$ and finally industries in Kilis employ 1129 people representing $8 \%$. When we take a look at the data presented, it is easy to notice the parallel relationship that exists between the number of industries and their sizes in a particular province and the number of people employed by these industries. Terror, raises transaction costs, reduces investments and increases public spending. Thus an increase in the risk of terror and uncertainty, restricts employment opportunities (Alp, 2013).

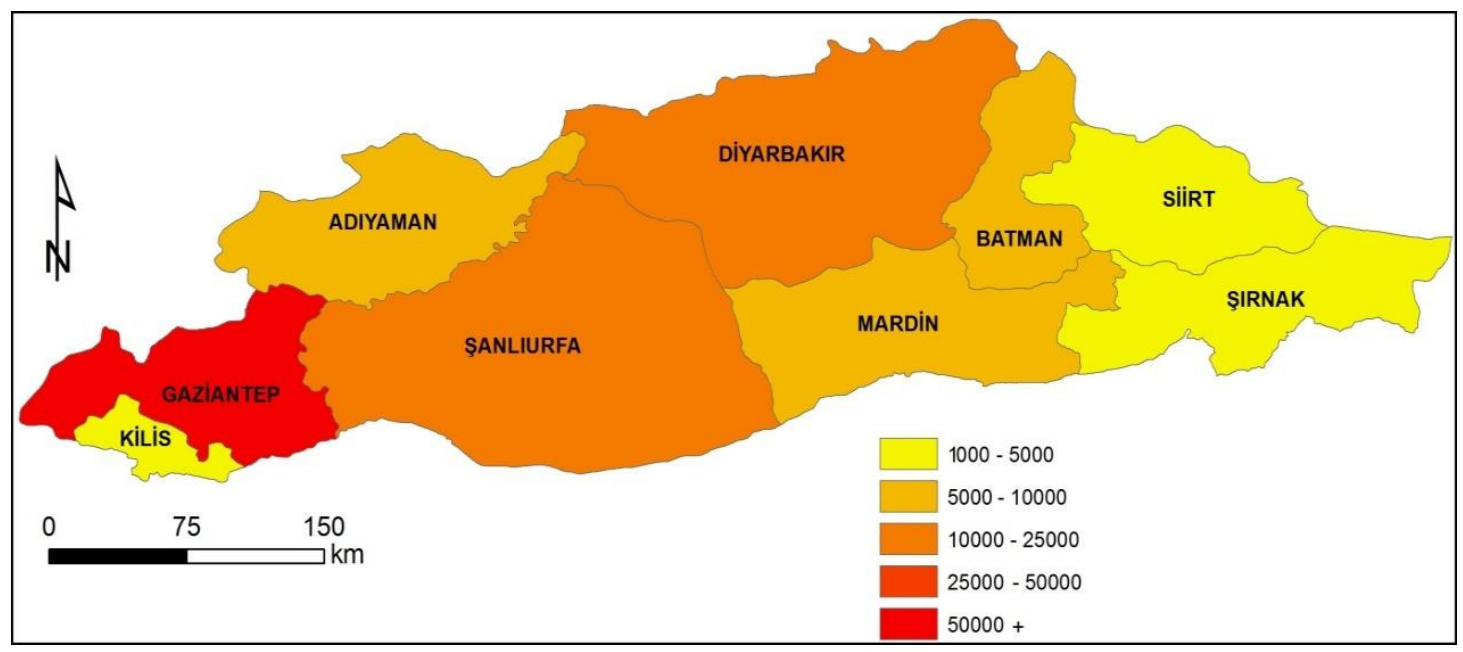

Figure 10. Distribution by province of the employees in the industrial sector in the region

From the figures above, we can see that the PKK is against local investment, but despite the attempts to block investments, the years 2010-2013 have seen per capita investments moving more towards the east where ethnic terrorism is concentrated in the region. In contrast, despite the eastern part receiving the most investment incentives, the western part which has less incentives received more private investments. Among these provinces, the most interesting is Gaziantep. Gaziantep province was established immediately after Turkey was declared a republic and in 1925 it was chosen to be among the 11 industrial zones. In 1969, a small industrial zone was established in Gaziantep and led to the emergence of an industrial tradition attracting capital from the surrounding provinces (Sönmez, 2012). Despite the number of incentives reaching considerable levels during the 
last years in many provinces in the south eastern region, many investors in Gaziantep do not regard the region as a good area for investment due to security reasons. It can be seen that the region's per capita share of the domestic national product has been affected by the growth of terrorist incidents and the general economic crisis. Indeed, the per capita share of the domestic national product was the lowest during the years 1993-94-95 when the number of terrorism related deaths was the highest. In a three year period only, Turkey experienced most terrorism related deaths, rising to 10,000 deaths and the more than half of these deaths were recorded in the south eastern Anatolia region (Figure 11). Therefore, the security problems in the region led to an increase in migration as well as the movement of capital from the region.

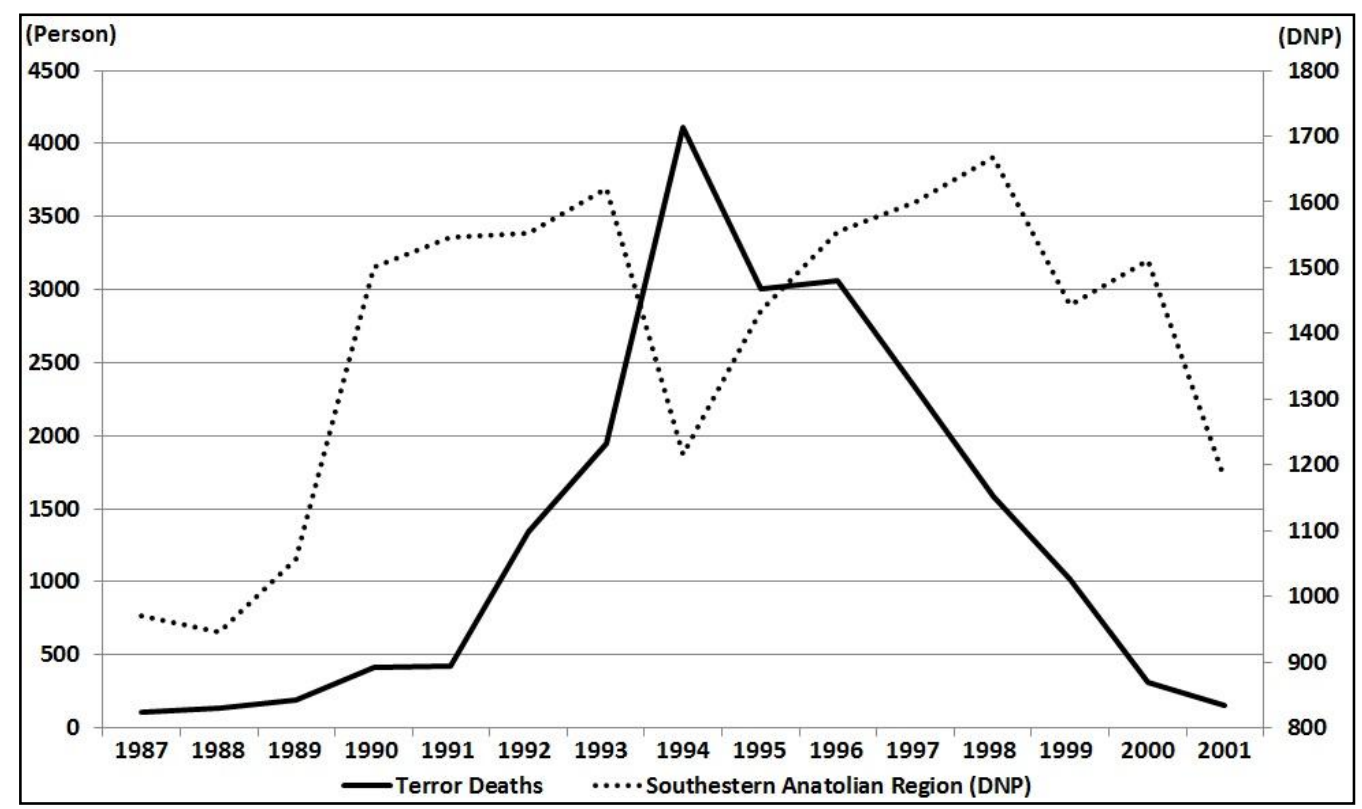

Figure 11. Terrorism related deaths

Economically, terrorism has been an extra cost to Turkey. Purchase of weapons for security purposed, military personnel expenditures and damages experienced from terrorist activities all needed economic support. For examples, between 1999 and 2011, transfer appropriations to people who wanted to return to the abandoned villages reached 128,360.00 Turkish Liras, public health insurance premiums were paid for 82724 people and $2,569,967.285$ was allocated to terror victims. In addition to this, from 18.11.2011, 8543 people were given associate military personnel status, 6483 were given military anti-terrorism status and 5034 people were given the village guards status. In this case 20060 people were on social security pensions under the Anti-Terrorism Act no.3713.

\subsection{The Factors Affecting the Investment Decisions in the Southeastern Anatolia Region of Turkey for Enterpreneurs Operating Gaziantep}

In order to reveal the relationship between terrorism and investments, a questionnaire was administered to firms exporting to at least one country and based in the South eastern Anatolia region of Turkey. A total of 92 companies participated in the survey. Thus, both the profiles of the firms investing in the region as well as factors that influenced that owners or shareholders to invest in the region were evaluated. According to the questionnaire, the educational background of the firms in the region are as follows; $44.56 \%$ are first degree holder, $11.95 \%$ are holders of masters degrees and above, $9.78 \%$ are holders of associate degrees, $5.43 \%$ graduated from arts high schools, 18,47 are high school graduates and the remaining $9.77 \%$ are primary and middle school graduates.

Whilst $51.64 \%$ of the firms are incorporated (joint stock) companies, $45.05 \%$ are Limited companies, $2.19 \%$ are ordinary companies and 1.09 are limited partnerships. $18.47 \%$ of the firms surveyed have a workforce of over 500, 7.6 has between 250-499 and 19.56 has between 50-249, 34.78 has between 10 and 49 and the remaining 19.56 employs 10 people and less.

In terms of export ability, $12.35 \%$ of the firms export to over 51 countries, $10.11 \%$ export to between 21 and 50 
countries and another $11.11 \%$ exports to between 11 and 20 countries, 14.6 exports to between 6 and 10 countries and the remaining $52.8 \%$ exports to between 1 and 5 countries.

$42.22 \%$ of the employers who participated in the survey feel there are no geographical barriers in investing in the South eastern Anatolia region, 30\% feel that there are few barriers whilst 27.77 feel that the geographical position of the region presents barriers to investment. Whilst 50\% do not find the migration of people in the region as a problem, $22.22 \%$ do see partly as a problem whilst 27.77 see this as a problem to investments in the region.

Entrepreneurs were asked how the lack of qualified workforce affects investments in the region; 43.18 of investors acknowledged that lack of qualified workforce negatively affects investments whilst $31.81 \%$ felt that the lack of qualified workforce does not affect investment in the region. Again, 25\% of investors acknowledged that lack of qualified workforce partly affects investment in the region.

The firms were asked how the lack of organized industry zones in the provinces of the South-eastern region would affect investment in the region; 38.04\% of the investors in the South-eastern Anatolia said that they view the lack of organized industry zones in most provinces hinders investments in the region. While $36.95 \%$ of the investors in the region don't think that the lack of organized industrial zone as an obstacle to investment in the South-eastern Anatolia region.

Entrepreneurs were asked about how the existence of Free Customs Zones in the provinces in South-eastern Anatolia would affect investments; While $66.66 \%$ of the investors interviewed acknowledged that the presence of a customs free zone will have a positive impact on investments, $15.55 \%$ thought that this would have a negative impact. $17.77 \%$ thought that the presence of a free customs zone would partly affect investment in the area.

When asked about whether the presence of alternative transportation means would have an impact on the investments in the region or not, $81.31 \%$ of investors responded by saying that other transportation means would have a positive impact whilst $9.89 \%$ said the absence of other transportation means should be seen as a factors that hinders investments in the region. 8.79\% said this would partly affect investments in the region.

Entrepreneurs were asked about how closeness to the market would affect investments in the region. Whist $71.73 \%$ of entrepreneurs said that the distance to the market is one of the reasons that influence investment decisions in the South eastern Anatolia region, $19.56 \%$ said the distance to the market partly affects investment decisions. But $8.69 \%$ said that the distance to the market does not affect them in making investment decisions.

Entrepreneurs were asked about their thoughts on the effects of the lack of adequate incentives on investments in the south eastern Anatolia region. 66.3\% of entrepreneurs responded by saying that the lack of investment incentives in the south eastern Anatolia region affects investment whilst $18.39 \%$ said that this factor partly affects investments in the region. Again $16.3 \%$ of investors do not see the lack of investment incentives as a factor that affects investments in the region.

When asked if the risk of terrorism in the south eastern Anatolia region, would be a barrier to their decisions to invest in the south eastern Anatolia region, Whilst 52.17\% of investors see terrorism as an obstacle to invest in the Southeastern Anatolia region, 21.73\% of investors said that terrorism partly hinders investment in the region. $26.08 \%$ of investors do not see terrorism as a barrier to investments in the region.

In terms of the potential political risk in the Southeastern Anatolia region in connection to its ambitions for autonomy, the study found out that $52.52 \%$ of investors expressed fear of uncertainty regarding the political future of the region as a barrier to investing in the region whist $21.73 \%$ felt that the political uncertainty in the region would partly affect investment decision in the region. Again $21.73 \%$ did not see the political uncertainty as a factor that affects investments in the region.

When investors were asked about whether the supply of raw material in the South-eastern Anatolia region does affect investment decisions or not, $45.55 \%$ of investors said the fact that the region is far from the sources of most raw materials contributes negatively to investment decision in the region and $24.44 \%$ of investors think that this partly affects investment decisions. $30 \%$ of investors did not see the distance to the source of raw materials as a barrier to investing in the region.

As to how the entrepreneurs would be affected by decisions of their competitors to invest in the South-eastern region, 55.55\% said that this would be a positive development, $31.11 \%$ of investors said that this would not have any impact on their businesses and $13.33 \%$ said that this would negatively affect their businesses in the region, $62.22 \%$ responded by saying this would positively affect their investment decisions whilst $20 \%$ of investors said this would not affect their investment decisions at all and $7.77 \%$ said that this would negatively affect their 
investment decisions.

When asked about how the cheap cost of labour in the South-eastern Anatolia region would affect their investment decisions in the region, $73.91 \%$ of investors said that this would have a positive impact on their investment decisions, $15.21 \%$ responded by saying this would have no impact on investment decisions and $10.86 \%$ said that the low cost of labour would be barrier to investments in the region.

Investors were asked about the influence of incidences of violence in the Middle East and its impact on investments in South-eastern Anatolia region. $48.35 \%$ of the investors said that the violence in the Middle East has cast a barrier on investments in the South-eastern region of Turkey. And $17.58 \%$ said that the violence in the Middle East will not have a positive impact on investments whilst $36.07 \%$ of investors responded by saying there will be no impact on investments in the South-eastern region of Turkey.

In response to the question of how social living conditions in the region would contribute to investments in the South-eastern Anatolia region; $34.06 \%$ of investors said that the social living conditions in the region will positively contribute to investment decisions. $35.16 \%$ of investors thought that the social living conditions would not affect their investment decisions and 30.76 said that the social living conditions would act as a barrier if they were to make a decision to invest in the South-eastern Anatolia region.

If the threat of terrorism in Southeast Anatolia disappear entirely, the investors were asked about how their potential investment ideas to do with the provinces in the South-eastern Anatolia region would be affected. $80.43 \%$ of investors said that this would have a positive impact on their investment perceptions for the region. $13.04 \%$ do not see terrorism as a barrier hence their investment decisions would not be affected whilst $6.52 \%$ of investors said this would have a negative impact on the investment decisions in the region.

When asked about what the investment opportunities would be like if all the conditions in the provinces in the Southeastern region were equal, Adiyaman would have 2.17 of investment share, Diyarbakır 2.17\%, 73.91\% in Gaziantep, Kilis 5.43\%, 9.78 for Mardin, Siirt 0\%, 4.34\% for Sanliurfa and Sirnak would have 2.17\% of total investment share.

When asked whether they would consider investing in other provinces in the Southeastern Anatolia region apart from Gaziantep, whilst $57.6 \%$ of investors said they are considering in other provinces, $42.39 \%$ said they are not considering in other provinces apart from Gaziantep. When asked what they think as barriers to investing in other provinces, $15.47 \%$ mentioned the distance to markets as a prohibiting factor, another $15.47 \%$ said transportation is a factor $9.52 \%$ mentioned the sourcing of raw materials as a problem, 44.04 cited the security problem as a hindering factor and $\mathbf{1 4 . 2 8 \%}$ was attributed to lack of human resource as a factor that hinders their investment decisions in the region.

If you ever invested in a province in the Southeastern Anatolia region, what was the problem that you experienced? $26.58 \%$ of investors replied by saying that they never faced any problems, $2.53 \%$ mentioned the problem of distance to markets, $8.86 \%$ said that they faced transportation challenges, $15.18 \%$ faced the procurement of raw materials challenges, $40.50 \%$ mentioned security challenges and $6.32 \%$ said that the biggest challenge they faced was lack of qualified human resource.

When asked about provinces which they would not consider for investment even if all the economic conditions were the same, $7.77 \%$ of investors said they would not consider to invest in Adiyaman, 5.55\% mentioned Batman, $7.77 \%$ in Diyabakır, 3.33\% in Mardin, 7.77\% in Siirt, 5.55\% in Şanlı Urfa and 40.33\% of investors said that they would not consider to invest in Şırnak.

When asked about the social impact of investing in other provinces in the South-eastern region, 29.34\% said that investing in another province in the South-eastern Anatolia region would have a positive impact on the social environment whilst $45.65 \%$ thought that this would not have any impact on the social environment and $25 \%$ of investors said that investing in another province in the South-eastern Anatolia region would have a negative impact on the social environment.

\section{Results}

\subsection{Simple Inquiry Findings}

\subsubsection{Education}

It can be seen that the majority of owners of firms were high school graduates and above. This is against the general population data in Turkey that puts businessmen to be mostly primary school graduates. This data provides us a good indication of the level of education and its importance to understanding the companies in Gaziantep. The lack of people in the graduate level and the insufficient level of university-industry cooperation 
or little or no contribution of research and science to industries can also be observed.

\subsubsection{Number of Employees}

It can be observed that one-fifth of the company's employees about 500 people or more. Most of the companies are family businesses and require prudent growth. Again, during the research it was observed that most of the firms were not yet institutionalised hence lacked professionalism due to lack of good management. The small numbers of employees was also attributed to the use of new production technologies which made the use of more man power unnecessary.

\subsubsection{Qualified Employees}

Firms expressed reservations to more investments and this was attributed to lack of qualified personnel. This could also be attributed to lack of value adding by vocational training schools for the past 10 years to produce enough and semi qualified personnel. However, the firms think that the region is not able to meet the required needs of personnel at graduate and undergraduate level that could supply the much needed technical staff. Families do not send their children to technical schools because they think they will in the end not be able to find a job in the region at the same time investors think they cannot invest in the region because they cannot find qualified personnel. So it's like a vicious blame cycle. Due to all these reasons, investors have fears of being unable to find qualified personnel.

\subsubsection{Organized Industrial Zones}

Organized industrial zones influence the ease for firms to make investment decisions. Some sectors will need the support of other sectors of production. Industries are interdependent. Therefore, it is expected that half of firms will be sensitive to how the industries are organized. Other firms may not feel the need due to the nature of their products. Here is a diagonal table that shows essential factors to be considered in an organized industrial zone. In summary, we can say that total production should be in a defined diameter of place. For example, among the concerns expressed by entrepreneurs in southeast Anatolia, was proximity to raw materials. Even mining firms inclusive, the issue of raw materials in these provinces is of concern due to the underdevelopment of the provinces.

\subsubsection{Transportation}

Approximately $15 \%$ of the firms that were asked felt that transportation is one of the obstacles that affect investment decisions in the South-eastern Anatolia Region. Firms operating in Gaziantep currently heavily rely on road and rail transport to the ports of Mersin and Iskendurun. However, other provinces in south eastern Turkey do not have these alternative transportation opportunities. In this region, apart from Gaziantep, it's very hard to reach the sea from the other provinces due to its proximity. At least the cheapest mode of transport to the sea from these provinces is using rail transport which in turn impacts on investment.

\subsubsection{Security}

The majority, $44 \%$ of firms see terrorism as an obstacle to investment in the region. Here the security problem is not just the risk that may occur outside the factory, it also has to be understood in the sense of the perception of personal security of the employees in the works place. Apart from Gaziantep, the most important hindering factor to investment is Security (38\%). If all conditions remained the same, $43 \%$ of the firms interviewed said they would never invest in Şırnak. And if there would have been no security problem in the South-eastern Anatolia region, investment rate would be up to $81 \%$ which is a very high rate. Despite the negative perception of security, $40 \%$ of investors in Southeast Anatolia apart from Gaziantep stated that they had security problems. However, this rate meant bad news and enough to scare potential investors from investing in the region. Leave $40 \%$, even a $1 \%$ of negative perception about security is enough to turn investors away. In this case, the negative security perception of the $26 \%$ of firms in South-eastern Anatolia apart from Gaziantep, has a negative impact on investment in the region and it can also be projected that this will continue to have adverse impacts on planned investments in the region. The general violence in the Middle East is different in this regard. As almost half of the firms interviewed (48\%) have the view that violence in the region has a negative impact on investments, $17 \%$ have a positive view of the region despite the violence. According the their evaluation, the availability of refugees in the region has made available cheap labour which has created an advantage of doing business in the region. As the war has created new markets and the need for new products from the industry and this has changed the perception of investments in the region.

\subsubsection{Government Support (Subsidy)}

Most companies have highlighted the lack of state support for investment. For entrepreneurs to invest in 
unattractive areas, the government can come up with investment laws that make these areas attractive. But compared to the other 6 regions in Turkey, the Southeast Anatolia region has more incentives. However, entrepreneurs do not see these incentives as enough. This is because the region does not have advantages in terms of availability of raw materials, alternative transport, geographical conditions as well as the threat of terrorism. This is one $66 \%$ of the investors interviewed did regards the incentives as enough. To reduce the regional economic disparities, the government should involve investors in infrastructure development planning and in this way, investment incentive measures would be organized in accordance with the requirements (Karg1, 2009, p. 37).

\subsubsection{Investment Outside Gaziantep}

Almost half of the firms (42\%) do not feel like there is an investment demand outside Gaziantep. However, if there could be no problems, most firms have the intention to invest in other provinces outside Gaziantep. The difference between the two rates is around $15 \%$. This data is important and promising for the integrity of the region. Because regional risk and security perceptions of the bourgeoisie and the productive forces constitute one of the main indicators for the future of that region. However, under the same conditions, due to safety reasons, Şırnak ranks first in terms of provinces where investors cannot go and invest. Again, Mardin provinces received positive perceptions from entrepreneurs based on security levels as well other criteria. Together with Gaziantep, Mardin came last on the list of provinces not considered for investment by entrepreneurs. If the question was asked inversely in terms of which provinces in the South-eastern Anatolia region they would most likely consider to invest in, Mardin came first with 9.78\%. In this case, apart from the location of Mardin other factors could also be playing a role. Geographically Mardin is the same as Şrnak and Kilis. But in case of Mardin, it could also be attributed to social factors. This could be one of the reasons why Mardin is preferred. Whilst 29\% consider social environment as a factor in making investment decisions, $25 \%$ doesn't consider the social environment. This shows that living conditions play an important role in making investment decisions.

This can also be compared between provinces which were considered as not preferred for investment like Hakkari and Kilis where by Kilis has an edge over Hakkari due to the significance of the social and cultural factors. We can say that this aspect needs more reviews. Much as this can be viewed as good news for Gaziantep and Kilis provinces, it could also be said that its bad news. There is a local perception in Gazantep that people from Kilis are regarded as more dangerous than snakes that if you put a snake and someone from Kilis in one sack, the snake would ask to be taken out of the sack. Likewise, people from Kilis have bad perceptions about people from Gaziantep. It is common to see jealousy growing between people in small provinces or settlements as well as for people from neighbouring provinces. Kilis being a border province is associated with smuggling and this is perceived to have a negative impact on people's attitude towards work. And again because the values are derived from the close social relationships and smuggling activities, this generates that negative perception of attitudes towards work and working relationships. To help remove this misconception, most enterpreneurs from Kilis with factories in Gaziantep prefer to employ their 'homeboys' from Kilis and thus provides transport for them to commute between Kilis and Gaziantep during work days. However, due to a jealousy, discontentment and misuse of the privileges attitudes which in turn affects production, this practice is slowly being abandoned. It can therefore be said that in this regard, that social environment presents the entrepreneur with another important challenge.

In fact, though considered as small (29\%), the social environment present similar challenges to enterpreneurs in other provinces. In this case, it can be said that the firms do not think and do their things in a more rational and proffesional way because to a certain extent they do their work according to the social environmental norms and behaviours. Here it also be noted that this depends on the individual firms and enterpreneurs.

\subsection{Cross-Questioning Results}

\subsubsection{Education}

There is a positive relationship between level of education and the number of workers employed in firms. According to the findings of the study, owners of firms which employ between 1-49 people have low education levels whilst the owners of all firms that employ 250 people and above as well as $67 \%$ of owners of firms employing 500 people and above are university graduates. Again, half of the owners of these (11 firms) have above first degree qualifications. These findings could offer us a clue as to the success of firms based in Gaziantep province. However, it is interesting to discover that firms whose owners are vocational and technical high school graduates do not employ more than 50 people. Whilst it was expected to have a high number of owners of firms who graduated from technical and vocational high schools, it was also discovered that middle school and normal high school graduates owned a few companies. This suggests that much as the vocational 
high schools could not produce semi-qualified personnel, they were also weak in the sense that they could not produce entrepreneurs. This trend is expected to continue especially with the education being offered in vocational high schools.

\subsubsection{Age}

Companies, just like people need time to grow. Experience with age are related to the extent of the size of the company and it's expected that the dynamic needs of companies require middle-aged managers. Indeed, the study found out that companies that export to more than 51 countries have are mostly managed by people who are aged between 35-54 years.

\subsubsection{Number of Export Markets}

If the findings of the study are anything to go by, every category (export markets), it can be seen the level of education is important. Generally speaking, as the level of education goes up, the number of export markets increases. We can therefore say that the education levels of owners of companies has a direct correlation with the number of export markets. In fact, the number of employees, the size of the company and the level of institutionalization affects the export capacity of the company. According to the findings of the study, $90 \%$ of companies that export to over 51 countries employ 500 people and above.

\subsubsection{Education Age and Investment Location}

In the findings, most company owners said that they would prefer to invest where they were born (half of them university graduates and the remaining half were those with lower educational qualifications). However, $90 \%$ of those that said place of birth would not be the determining factor for place of investment were university graduates. In this sense, it would be suggested that as education levels go up, entrepreneurs take more rational and not emotional investment decisions. Instead of having a home boy syndrome they look at other factors that have a direct impact on investment.

From the finding of this study, whist every age group has a different perception about the importance of investing in a home province, the 35-54 years age group showed that they think more widely that just investing in an area they come from. From the findings, $34 \%$ of those that said they would invest in their home area were between the ages of 18 years and 34 years old whilst those between 35 years and 54 years said they would not invest in area on the basis that they come from that area.

\subsubsection{The Risk of Terrorism and the Thought of Investment}

Both male and female entrepreneurs explained that terrorism would affect their investment decisions. A significant number of women (46\%) and the majority of men (53\%) saw terrorism as a hindrance to investment in the Southeast Anatolia region. With regards to this question, the percentage of those who thought that terrorism partly influences their investment decision can be said to be high. In case of political risk, 55\% of men and $60 \%$ of women said that it affects their investment decisions. Looking at the data those that gave 'partly' as an answer mentioned both the threat of terror and political risk as the contributing factors to investment decision and this was true for all age groups. 55\% of entrepreneurs aged 55 years and older mentioned that they evaluate the political risk before making investment decisions in the South-eastern Anatolia region compared to $80 \%$ of entrepreneurs of other ages. With other factors kept constant, as the age increases, the attention to risk in investment decisions also increases. The percentage of those who believe that terrorism is not a problem for investments in the Southeast Anatolia region according to age groups is as follows; 18-34 years age group 18\%, $35-54$ years age group 30\%. In all the education categories, $58-60 \%$ said that the political risk in the south-eastern Anatolia region affects their investment decisions. But when you look at all education categories, $20 \%$ of entrepreneurs said that the political risk in the region would not affect their investment decisions. However, the percentage of those who said they would not be affected was high for entrepreneurs who are primary school graduates. Similarly, those that think that terrorist activities in the region excluding primary and middle school graduates generally is the same percentage (60\%). Perhaps we can say that the higher the level of education the higher the risk perception. The more the formal the level of education increases, the more rational entrepreneurs think about risk assessment. It can also be seen that the bigger the size of the firm the more the owners consider the risk of terror as a hindrance to investment in the south-eastern Anatolia region. In this regards, while 38 to $56 \%$ of owners of companies employing 249 people and below see terrorism as a hindrance to investments in the region, $71 \%$ of owners of companies employing more than 500 people see terrorism as a hindrance to investments in the region. The same can be said with the proportion of export markets. Thus, companies exporting to from 21-50 countries (23-53\%) while companies exporting to 50 countries and above (66-71\%). This factors also took into account the birthplace of the entrepreneurs. Just as the companies pay 
attention to any kind of risk, the risk of terror is expected to demand more attention due to its sensitivity. However, due to the frequent occurrences of violence in the Middle East, entrepreneurs started perceiving the risk in the south-eastern Anatolia region as low. This is why entrepreneurs said that their investment decisions are not affected by violence (34\%) and those that thought the incidences of violence will affect their investment decisions was $48 \%$. As it is well known, most entrepreneurs and wealthy people have moved their capital from the Eastern and Southern Anatolia region to the western side of Turkey. In fact, this process can be looked at together with the periodic migration from these the region. This is also reflected in daily news from the region where you hear about kidnappings of employees and sometimes the burning or destruction of machinery which does not give hope to even the few entrepreneurs present in the region. It is because of such events that cause entrepreneurs to give up investing in the south-eastern Anatolia region. Terrorist activities instead of building the region destroy the region and entrepreneurs pay attention to the news coming from the region as well the risk of terror in the region and this makes them not consider taking steps to invest in the region. Leave aside the need for raw materials, transportation, probably the basic and simple investment needs such as energy supply are also a problem due to the illegal use of electricity which cause transformers and how can these frequent power cuts meet the infrastructure development needs?

\section{Discussion}

Because of the problems that terrorist attacks have brought especially on the economic development that other studies might have looked at, this study focusses on the relationships between terrorist attacks and investments using quantitative data and this has been evaluated and commented on. This is why the results obtained can be qualified as being objective and having scientific properties. According to these data; it can be concluded that investment in the south-eastern Anatolia region is to a large extent influenced by terrorist activities. In this case particularly in provinces with high terrorist activities and with high terrorism related death occurrences. And indeed, in provinces with intense terror incidences, level of private investment consideration is very minimal. In contrast, especially in provinces in the west where the level of support to terrorist has been reduced, the rate of investment is fast increasing. This is closely related to the feeling of capital safety by the investors. For example, government support and incentives are high but due to the high terror incidences in provinces like Şrrnak, Diyarbakır, Siirt investment rates are still low and in Gaziantep and Şanliurfa provinces where government support and investment incentives are low but still the investment thought can be seen to be high. To make matters worse, the news coming from the region the demands for autonomy from political parties that enjoy good support in the region has led to emergence of concerns over the future of the region. Therefore, investors are concerned about the future of the region and this negatively affects the investment demand. The continuation of this uncertainty could lead to postponement of decisions to invest in the region. During the face to face interviews with investors, they expressed that the most important hindrance to investment in the region is uncertainty. This is why it is important to solve the security issues in the region if the development gap between the provinces in the region is to be closed. Otherwise, there will gradually be a deepening economic gap in the region, which could result in many social, economic and political remaining unresolved.

In this study, it can be seen that in provinces with high terrorist incidences of Sirnak and Mardin, total investment rates are $20 \%$ of investments in Gaziantep province. The same investors indicated that in the south-eastern region, they would prefer to invest in Gaziantep due to security reasons as well as uncertainty regarding the future of the region. Indeed investors that participated in the study showed reluctance to invest in their place of birth especially in the south eastern provinces and apart from Gaziantep they said they would prefer to invest in the western parts of the country. For examples, some investors in the region said they would never invest in Şırnak. This goes down to security reasons. As a result, the study concluded that a tight inverse relationship between the investment preferences intensity of terrorism activities. The uncertainty regarding the future of the region as well causes further escalation of this inverse relationship. This is why it is important that the policies for the region should aim at coming up with projects that will solve the terrorism problem in the region. Otherwise, the economic gap that exists between the regions will reach serious levels and may result in negative social, political, demographic consequences.

\section{References}

Abadie, A., \& Gardeazabal, J. (2003). The economic costs of conflict: A case study for the Basque country. American Economic Review, 93(1), 113-132. http://dx.doi.org/10.1257/000282803321455188

Alp, İ. A. (2013). Terörün Ekonomik Etkileri. Uluslararası Güvenlik ve Terörizm Dergisi, pp. 1-19.

Arslan, İ., \& Mete, M. (2007). Türkiye' de Bölgesel Kalkınma Politikaları (İzmir İli İçin Sektörel Yatırım Teşvik Belgeleri ile İstihdam Analizi 1980-2006). İzmir Ekonomisinin Sanayileşme Sorunları (pp. 35-42). İzmir: 
Yaşar Üniversitesi.

Avcı, S. (2003). Gelişimi ve Sorunları Açısından Türkiye' de Şehirleşme. Sırrı Erinç Sempozyumu, Genişletilmiş Bildiri ÖZetleri (pp. 218-224). İstanbul.

Baharçiçek, A. (2000). Etnik Terör ve Etnik Terörle Mücadele Sorunu. Firat Üniversitesi Sosyal Bilimler Dergisi, 1(10), 11-27.

Bal, İ. (2007). Pkk Terör Örgütü: Tarihsel Süreç ve 28 Mart Diyarbakır Olayları Analizi. Usak, 2(8), 75-89.

Brück, T., Schneider, F., \& Karaisl, M. (2007). Research Project. DIW Berlin, European Commission, Directorate General Justice, Freedom and Security. Berlin: Deustches Institut Für Wirtschaftsforschung.

Brucka, T., \& Wickstro, B. A. (2004). The economic consequences of terror: Guest editors' introduction. European Journal of Political Economy, (20), 293-300. http://dx.doi.org/10.1016/j.ejpoleco.2004.03.004

Çetin, M. (2006). Teori ve Uygulamada Bölgesel Sürdürülebilir Kalkınma. C.Ü. İktisadi ve İdari Bilimler Dergisi, Cilt 7, Sayı 1, 1-20.

Chesney, M., Reshetar, G., \& Kahraman, M. (2011). The impact of terrorism on financial markets: An empirical study. Journal of Banking \& Finance, (35), 253-267. http://dx.doi.org/10.1016/j.jbankfin.2010.07.026

Cukierman, A. (2004). Comment on: "Macroeconomic consequences of terror: Theory and the case of Israel". Journal of Monetary Economics, (51), 1003-1006. http://dx.doi.org/10.1016/j.jmoneco.2004.05.002

Dow, J., \& Werlang, S. R. (1992). Uncertainty aversion, risk aversion, and the optimal choice of portfolio. Econometrica, 60(1), 197-204. http://dx.doi.org/10.2307/2951685

Ecksteina, Z., \& Tsiddon, D. (2004). Macroeconomic consequences of terror: Theory and the case of Israel. Journal of Monetary Economics, (51), 971-1002. http://dx.doi.org/10.1016/j.jmoneco.2004.05.001

İşeri, R. (2008). Türkiye' de Etnik Terör: Asala ve Pkk Örneği. Ankara: Atılım Üniversitesi Sosyal Bilimler Enstitüsü Kamu Yönetimi ve Siyaset Bilimi Anabilim Dalı Basılmamış Yüksek Lisans Tezi.

Karg1, N. (2009). Bölgesel Kalkınma Yaklaşımlarındaki Gelişmele ve AB. International Journal of Economic and Administrative Studies, 19-40.

Lakdawallaa, D., \& Zanjani, G. (2005). Insurance, self-protection, and the economics of terrorism. Journal of Public Economics, (89), 1891-1905. http://dx.doi.org/10.1016/j.jpubeco.2004.06.008

Llussá, F., \& Tavares, J. (2011). Which terror at which cost? On the economic consequences of terrorist attacks. Economics Letters, (110), 52-55. http://dx.doi.org/10.1016/j.econlet.2010.09.011

Malik, Z., \& Zaman, K. (2013). Macroeconomic consequences of terrorism in Pakistan. Journal of Policy Modeling, (35), 1103-1123. http://dx.doi.org/10.1016/j.jpolmod.2013.08.002

Öztürk, S., \& Çelik, K. (2009). Terörizmin Türkiye Ekonomisi Üzerine Etkileri. Alanya İşletme Fakültesi Dergisi, 85-106.

Sboui, A. N., \& Hammas, M. A. (2010). Regional Growth in the Euro Mediterranean Countries: Effects of Increasing Retunes and Spatial Externalities. International Journal of Economics and Finance, 40. http://dx.doi.org/10.5539/ijef.v2n1p40

Sezgin, Ş., Gündüz, N., \& Sezgin, S. (2008). Güneydoğu Terörünün Ekonomik Sonuçları. Akademik İncelemeler, $3(1), 1-17$.

Shahrestani, H., \& Anaraki, N. K. (2008). Productivity versus productivity and economic growth: Empirical evidence from selected countries. International Business \& Economics Research Journal, 7(10), 43-52.

Sönmez, M. E. (2012). Yerleşme Yeri Seçimi ve Alansal Gelişimi Açısından GAZİANTEP. Malatya: Özserhat Yayincilik.

TBMM. (2013). Terör ve Şiddet Olayları Kapsamında Yaşam Hakkı İhlallerini İnceleme Raporu.

Töreli, T. (2002). PKK TERÖR ÖRGÜTÜ (Tarihsel ve Siyasal Gelişim Süreci Bakımından İncelenmesi) 1978-1998. Isparta: Süleyman Demirel Üniversitesi Sosyal Bilimler Enstitüsü Tarih anabilim Dalı Basılmamış doktora Tezi.

TÜIKK.

(2014).

Retrieved

from http://rapory.tuik.gov.tr/26-12-2014-13:33:28-7286126004984177491693953941.html adresinden alınd1

Unur, K. (2000). Turizm-Terörizm İlişkisi ve Türkiye Örneği. Anatolia: Turizm Araştırmaları Dergisi, (11), 
169-177.

Yayar, R., \& Demir, Y. (2012). Bölgesel Kalkınma ve Yatırım Teşvikleri. Erciyes Üniversitesi İktisadi ve İdari Bilimler Fakültesi Dergisi, 119-146.

Yeşiltaş, M., Öztürk, İ., \& Türkmen, F. (2008). An Assessment in the Perspective of Possible Solutions for Terror Effects on Tourism Sector. Sosyal Bilimler Dergisi, X(1), 175-189.

\section{Copyrights}

Copyright for this article is retained by the author(s), with first publication rights granted to the journal.

This is an open-access article distributed under the terms and conditions of the Creative Commons Attribution license (http://creativecommons.org/licenses/by/3.0/). 